\title{
EFFECT OF DIFFERENT POLYMER AND OLEIC ACID ENCHANCER IN NIFEDIPINE MATRIX TRANSDERMAL PATCH FORMULATION AND EVALUATION
}

\author{
B. Togatorop ${ }^{1}$, K.R. Sinaga ${ }^{1}$, E. Suwarso ${ }^{2}$ and I. Iksen ${ }^{3, *}$ \\ ${ }^{1}$ Department of Pharmaceutical Technology, University of Sumatera Utara, \\ Medan-20155, Indonesia \\ ${ }^{2}$ Department of Pharmacology, University of Sumatera Utara, Medan-20155, Indonesia \\ ${ }^{3}$ Department of Pharmacy, Sekolah Tinggi Ilmu Kesehatan Senior, Medan-20131, Indonesia \\ *E-mail :ikseniksen08@gmail.com, baharuddinedy@gmail.com
}

\begin{abstract}
Nifedipine is an antihypertensive drug that has acted as a calcium channel antagonist. Nifedipine has a short $\mathrm{t}^{1 / 2}$ and hence its oral use should be in a more frequent frequency. This will affect the patient's compliance in taking the drug. To overcome this problem, the transdermal route drug delivery system can be an alternative. This study aims to find out the effect of the different polymer and the oleic acid enhancer on the characteristic of matrix transdermal patch. The patch was made in six formulas comprising polymer combination of ES-PVP (F1, F2, F3) and ES-HPMC (F4, F5, F6). The patch is formulated with solvent evaporation techniques. The dried patch was then evaluated for its physicochemical characteristics evaluation and in vitro release profile. The characteristic test result shows that the nefedipine patch is yellow, odorless and flat surface. The thickness is between $0.0196 \pm 0.0001 \mathrm{~cm}$ to $0.0003 \pm$ $0.0003 \mathrm{~cm}$. Uniformity of weight is between $91.16 \pm 0.26 \mathrm{mg}$ to $95.16 \pm 0.12 \mathrm{mg}$. \% moisture content is between $1.1068 \pm 0.5849 \%$ to $4.8602 \pm 0.4255 \%$. Drug content $96.90 \pm 1.83 \%$ to $99.38 \pm 0.22 \%$. The drug release follows the Higuchi order. The highest penetration result was found in formula 6 with a polymer composition of ES:HPMC ( $16.25 \mathrm{mg}: 48.75 \mathrm{mg}$ ) of $88.77 \%$ for 24 hours. From this study it can be concluded that the $6^{\text {th }}$ formula is the best which can be observed from its physicochemical characteristics and in vitro release profile.
\end{abstract}

Keywords: Nifedipine, Transdermal, Polymer, Enhancer, Oleic acid.

(C) RASĀYAN. All rights reserved

\section{INTRODUCTION}

Transdermal drug delivery system has been increased interest in the drug administration via skin as well as for local therapeutic and systemic drug delivery system. ${ }^{1}$ Trasndermal drug delivery system has many advantages over the oral route of administration such as avoid gastric irritation problem and hepatic firstpass metabolism, increasing the bioavailability of drug, reduce the side effect of systemic drug delivery system, avoid pain associated with injection and improving patient compliance since the frequent intake of the drug is not necessary. ${ }^{2-5}$ Nifedipine (Fig.-1) is used in the treatment of antihypertensive, angina pectoris and anti-atherosclerotic. ${ }^{6-9}$ It has a molecular weight 346.34. In the oral usage, nifedipine is rapidly and almost perfectly absorbed $(90 \%)$ in the stomach, but having a first pass metabolism, it results in a low bioavailability and around $95 \%$ will be bounded to the plasma proteins. Nifedipine has a short $\mathrm{t}^{1 / 2}$ and hence its oral use should be in a more frequent frequency. This will affect the patient's compliance in taking the drug. Nifedipine has an ideal character to be made in transdermal dosage form, since it has a molecular weight less than $500 \mathrm{Da}$ and a small dose range $(10-40 \mathrm{mg})$, with a low oral bioavailability. ${ }^{10,11}$ From the above-mentioned factors, it made nifedipine a suitable candidate for the transdermal route drug delivery system.

\section{Materials}

\section{EXPERIMENTAL}

The materials for the transdermal formulation of nifedipine are nifedipine (from Kimia Farma Bandung), ethyl cellulose (ES), polyvinylpyrrolidone (PVP), hydroxypropyl methyl cellulose (HPMC), oleic acid, glycerin. All the ingredients were of analytical grade. 


\section{Formulation of Matrix Transdermal Patch}

Matrix transdermal patch of nifedipine was prepared by the solvent evaporation technique. The polymeric solvent was prepared by dissolving the active substance (nifedipine), different ratio of polymer (ES, PVP and HPMC), oleic acid and glycerin in the blend of ethanol and chloroform (1:1) with the help of stirrer. The polymeric mixtures then poured into the mold and kept at a room temperature until dry. The formula design of nifedipine matrix transdermal patch is shown in Table-1.<smiles>COC(=O)C1=C(C)NC(C)=C(C(=O)OC)C1c1ccccc1[N+](=O)[O-]</smiles>

Fig.-1: Structure of Nifedipine

Table-1: Compositions of 6 formula of Nifedipine Matrix Transdermal Patch

\begin{tabular}{c|c|c|c|c|c|c}
\hline \multirow{2}{*}{ Composition } & \multicolumn{7}{|c}{ Formula } \\
\cline { 2 - 7 } & F1 & F2 & F3 & F4 & F5 & F6 \\
\hline Nifedipine (\%w/w) & 10 & 10 & 10 & 10 & 10 & 10 \\
\hline ES (\%w/w) & 48.75 & 32.5 & 16.25 & 48.75 & 32.5 & 16.25 \\
\hline PVP (\%w/w) & 16.25 & 32.5 & 48.75 & - & - & - \\
\hline HPMC (\%w/w) & - & - & - & 16.25 & 32.5 & 48.75 \\
\hline Oleic acid (\%w/w) & 5 & 5 & 5 & 5 & 5 & 5 \\
\hline Glycerin (\%w/w) & 20 & 20 & 20 & 20 & 20 & 20 \\
\hline
\end{tabular}

\section{Evaluation of Nifedipine Matrix Transdermal Patch}

\section{Visual}

The visual matrix transdermal patch parameters are color, texture and odor. ${ }^{12}$

\section{Thickness}

The thickness of films was measured by micrometer screw at five different sites and an average of five readings was taken with $\mathrm{SD} .{ }^{12}$

\section{Weight Variation}

The weight variation five patches were weighed on an electronic balance and the average of weight was taken with SD. ${ }^{12}$

Moisture Content

Individual films were weighed repeatedly until they showed a constant weight. ${ }^{12}$

$\%$ of Moisture content $=\frac{\text { Initial weight }- \text { final weight }}{\text { final weight }} \times 100 \%$

\section{Moisture Uptake}

The percentage of moisture uptake was calculated as the difference between final and initial weight with respect to initial weight. ${ }^{12}$ 
$\%$ of Moisture uptake $=\frac{\text { Final weight }- \text { Initial weight }}{\text { Initial weight }} \times 100 \%$

\section{Folding Endurance}

A strip of film was folded at the same place till it broke. The number of time the film can be folded at the same place without breaking was the folding endurance value. ${ }^{13}$

\section{Drug Content}

A $3.14 \mathrm{~cm}^{2}$ film was cut into small pieces and put it into a $100 \mathrm{ml}$ phosphate buffer $(\mathrm{pH} 7.4)$ and ultrasonicated for 30 mins with a stirrer. After filtration, the drug was estimated spectrometrically at 238 $\mathrm{nm}$ wavelength and determined the drug content compared using the calibration curve of nifedipine. ${ }^{12}$

\section{In VitroSkin Permeation Studies}

Male rabbits weighing between $1.5-2 \mathrm{~kg}$ were selected for the in vitro studies. The hair on abdominal region was removed using a razor knife (Gillette Goal) without breaking the stratum corneum. On the day of the experiment, animals were sacrificed by cervical dislocation and the abdominal skin was excised. The fatty material adhered to the dermis was carefully peeled off. The transdermal patch then placed on the fresh skin. Penetration study was performed by using a modified Franz diffusion cell. The samples were withdrawn at different time intervals and analyzed for drug content spectrophotometrically. ${ }^{12}$

\section{Evaluation of Nifedipine Matrix Transdermal Patch}

\section{RESULTS AND DISCUSSION}

The visual evaluation study reveals that there were no physical changes in color, texture and odorless between F1-F6. Table-2 and Fig.-2 showed the result from the visual patch.

Table-2: Visual Evaluation of Nifedipine Patch

\begin{tabular}{c|c|c|c}
\hline Formula & Color & Odor & Texture \\
\hline F1 & Yellow & Odorless & Flat surface \\
\hline F2 & Yellow & Odorless & Flat surface \\
\hline F3 & Yellow & Odorless & Flat surface \\
\hline F4 & Yellow & Odorless & Flat surface \\
\hline F5 & Yellow & Odorless & Flat surface \\
\hline F6 & Yellow & Odorless & Flat surface \\
\hline
\end{tabular}

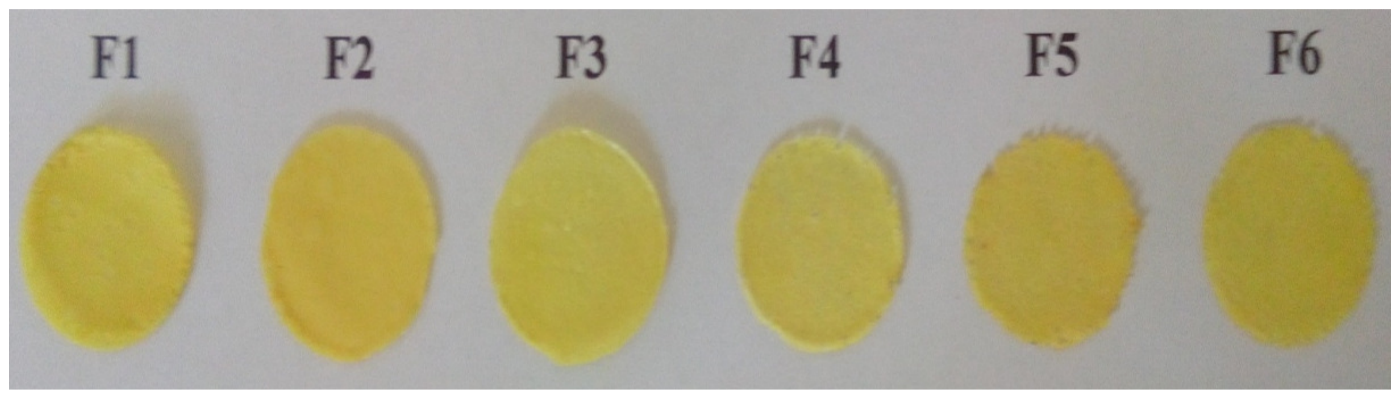

Fig.-2: Visual Evaluation of Nifedipine Patch

Table-3: Result of Physicochemical Evaluation of Nifedipine Patch

\begin{tabular}{c|c|c|c|c|c}
\hline \multirow{2}{*}{ Formula } & \multicolumn{5}{|c}{ Physicochemical Parameter } \\
\cline { 2 - 6 } & $\begin{array}{c}\text { Thickness } \\
(\mathrm{mm})\end{array}$ & $\begin{array}{c}\text { Weight } \\
(\mathrm{mg})\end{array}$ & $\begin{array}{c}\text { Moisture Content } \\
(\%)\end{array}$ & $\begin{array}{c}\text { Moisture } \\
\text { Uptake }(\%)\end{array}$ & $\begin{array}{c}\text { Folding } \\
\text { Endurance }\end{array}$ \\
\hline F1 & $0.0196 \pm 0.0001$ & $92.32 \pm 0.44$ & $3.4658 \pm 0.1139$ & $1.3090 \pm 0.0681$ & $\geq 300$ \\
\hline F2 & $0.0225 \pm 0.0003$ & $93.14 \pm 0.15$ & $4.2594 \pm 0.1377$ & $1.6449 \pm 0.2597$ & $\geq 300$ \\
\hline
\end{tabular}


RASĀYAN J. Chem.

Vol. 11 | No. 2 |516 - 521 | April - June | 2018

\begin{tabular}{c|c|c|c|c|c}
\hline F3 & $0.0251 \pm 0.0004$ & $95.16 \pm 0.12$ & $4.8602 \pm 0.4255$ & $2.2060 \pm 0.4522$ & $\geq 300$ \\
\hline F4 & $0.0240 \pm 0.0005$ & $90.24 \pm 0.11$ & $1.1068 \pm 0.5849$ & $0.3356 \pm 0.1105$ & $\geq 300$ \\
\hline F5 & $0.0273 \pm 0.0004$ & $91.16 \pm 0.26$ & $2.0405 \pm 0.6046$ & $0.5946 \pm 0.1676$ & $\geq 300$ \\
\hline F6 & $0.0303 \pm 0.0003$ & $94.10 \pm 0.18$ & $2.4693 \pm 0.2234$ & $0.9042 \pm 0.1256$ & $\geq 300$ \\
\hline
\end{tabular}

*Values are given as Mean \pm SD for triplicate

Formula 6 was having the thickness layer when compared to another formula which is due of HPMC. HPMC has a swelling activity which can swell in the solvent. The higher concentration of HPMC, the thicker layer that will obtain. Formula 3 showed the heaviest patch when compared to another formula. It can happen because of the higher concentration of PVP, the heavier weight will be obtained. PVP is a hygroscopic agent which can absorb the air and increase the weight. ${ }^{14}$

For the moisture content and moisture uptake result, all the formula show good percentage in the range of $1-10 \%$ which can be accepted. ${ }^{15}$ Folding endurance result showed that all the formula can be accepted. ${ }^{16}$ All the physicochemical evaluation are shown in Table-3.

\section{Drug Content}

The beginning step to determine drug content is to make the calibration curve. The calibration curve of nifedipine was made using various concentration (10, 50, 90, 130, 170, 210, 250, and $300 \mathrm{ppm}) .238 \mathrm{~nm}$ wavelength was used for the detection of nifedipine. Fig.-3 showed the calibration curve of nifedipine. The regression equation for nifedipine is $\mathrm{Y}=0.00246 \mathrm{X}+0.0061$ with 0.99956 for the coefficient correlation which can be accepted which the value of coefficient correlation should not smaller than $0.995{ }^{17-20}$ The result of the nifedipine content in the nifedipine matrix transdermal patch can be accepted according to the APVMA Guidline (2004) (Table-4). ${ }^{21}$ All the result for drug content is given as mean \pm SD for triplicate.

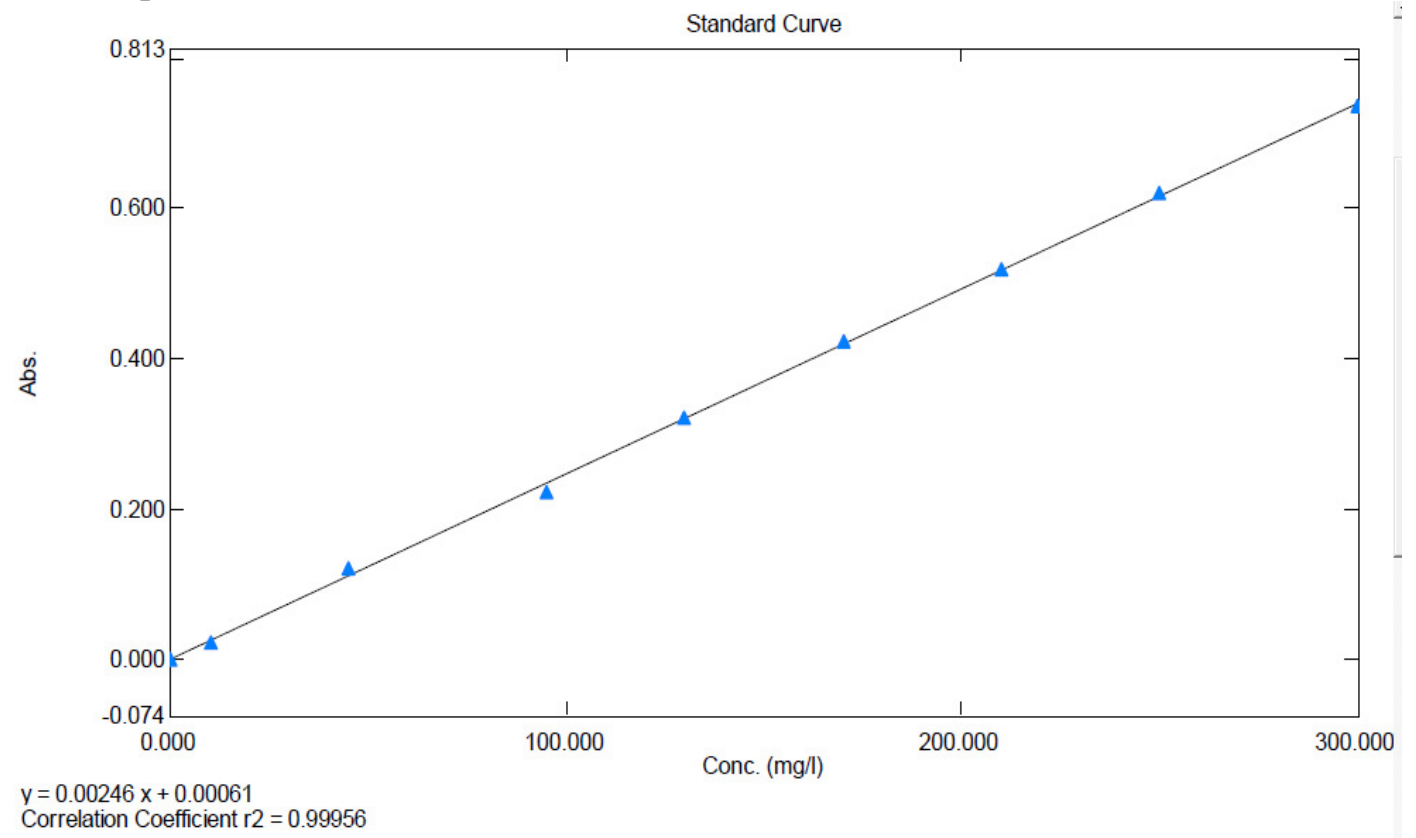

Fig.-3: The Calibration Curve of Nifedipine

\section{In VitroSkin Permeation Studies}

The drug diffusion from transdermal patch was followed Higuchi release pattern which is presented in Table-5. The in vitro pereation studies using rabbit skin revealed that nifedipine is possible with the transdermal patch. The maximum percentage release was attained within $24 \mathrm{~h}$ (Fig.-4). The delivery system was found to release $88.77 \%$ of the loaded drug at the end of $24 \mathrm{~h}$. Formula 6 showed the best drug release from the nifedipine matrix transdermal patch. 
Table-4: The result of drug contains test

\begin{tabular}{c|c}
\hline Formula & Drug Contain (mg) \\
\hline F1 & $96.90 \pm 1.83$ \\
\hline F2 & $98.50 \pm 1.51$ \\
\hline F3 & $98.18 \pm 0.23$ \\
\hline F4 & $97.16 \pm 0.54$ \\
\hline F5 & $97.03 \pm 1.58$ \\
\hline F6 & $99.38 \pm 0.22$ \\
\hline
\end{tabular}

Table-5: The Kinetics of Nifedipine release from the Nifedipine Matrix Transdermal Patch

\begin{tabular}{c|c|c|c|c}
\hline \multirow{2}{*}{ Formula } & Zero Order & First Order & Higuchi & Korsmeyer-Peppas \\
\cline { 2 - 5 } & $\mathrm{R}^{2}$ & $\mathrm{R}^{2}$ & $\mathrm{R}^{2}$ & $\mathrm{R}^{2}$ \\
\hline F1 & 0.967 & 0.868 & 0.989 & 0.981 \\
\hline F2 & 0.978 & 0.889 & 0.983 & 0.968 \\
\hline F3 & 0.978 & 0.871 & 0.981 & 0.978 \\
\hline F4 & 0.962 & 0.837 & 0.996 & 0.989 \\
\hline F5 & 0.982 & 0.887 & 0.987 & 0.974 \\
\hline F6 & 0.97 & 0.865 & 0.994 & 0.974 \\
\hline
\end{tabular}

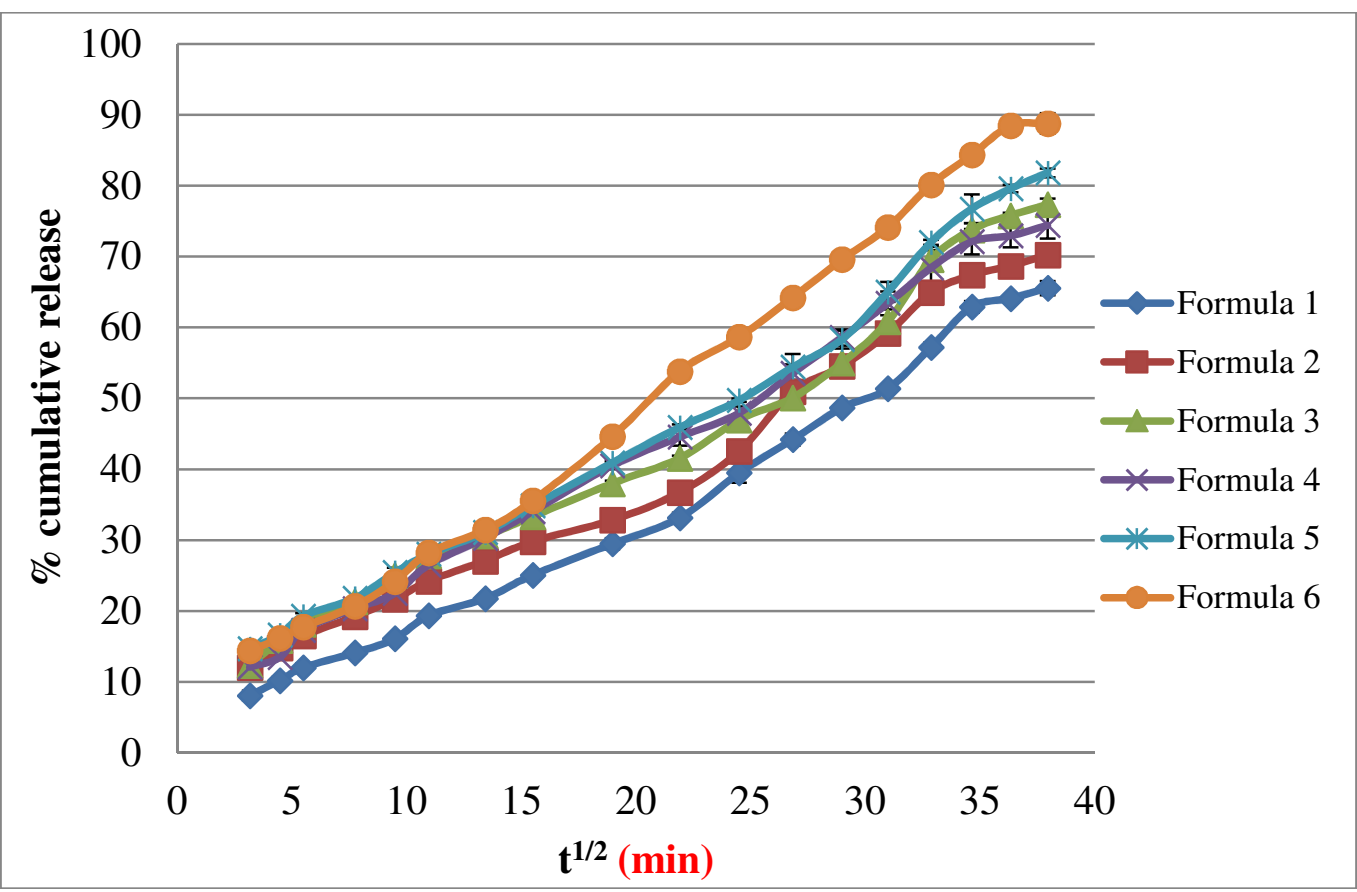

Fig.-4: The Percentage of drug release according to Higuchi model

\section{CONCLUSION}

The different polymer (ES, PVP and HPMC) and oleic acid enhancer used in this study showed that it can be used and showed good mechanical performance in visual, physicochemical and in vitro permeation test. Based on the observations, it can be concluded that the formulation and evaluation of nifedipine matrix transdermal patch using three combinations of polymers and oleic acid enhancer were found to be 
successful in the release of the drug for an extended period of 24 hours. However, the pharmacodynamic and pharmacokinetic evaluation of this system in animals and human volunteers is necessary to confirm.

\section{ACKNOWLEDGMENT}

The authors wish to thank the Kimia Farma Bandung for the nifedipine sample. We thank Faculty of Pharmacy, Universitas Sumatera Utara, Indonesia for the support.

\section{REFERENCES}

1. S.S. Kumar, B. Behury, P. Sachinkumar, Dhaka Univ, J. Pharm. Sci.,12(1), 63 (2013).

2. V.N.L. Sirisha, P. Kirankumar, M. Chinna Eswaraiah, IOSR Journal of Pharmacy, 2(5), 31 (2012).

3. S.E. Cross, M.S. Robert, Drug Develop. Res., (46), 309 (1999), DOI: 10.1002/(SICI)10982299(199903/04)46:3/4<309::AID-DDR17>3.0.CO;2-H.

4. B.C. Finnin, T.M. Morgan, J. Pharm. Sci., 88(10), 955 (1999), DOI: 10.1021/js990154g.

5. R. Kumar, A. Philip. Trop. J. Pharm. Res., 6(1), 633 (2007)

6. K. Derakhshandeh, M. Soleymani. Asian Journal of Pharmaceutics, 4(4), 185(2010), DOI: 10.4103/0973-8398.76739.

7. J.S. Grundy, R.T. Foster, Clin. Pharmacokin ,30(1), 25(1996), DOI: 10.2165/00003088$199630010-00003$.

8. R.D. Howland, M.J.M. Lippincott, Reviews Pharmacology, Lippincott Williams and Wilkins, Philadelphia, p.211 (1997).

9. F.R. Sheeba, G.D. Acharya, B.M. Reddy, S. Rameshwari, J. Anandhi, Asian J. Pharm. Clin. Res., 2(3), 44 (2009).

10. A.C. Moffat, M.D. Osselton, B. Widdop, Clark's Analysis of Drugs and Poisons, Pharmaceutical Press, London, p. 911 (2004).

11. K. Saroha, B. Yadav, B. Sharma, International Journal of Current Pharmaceutical Research, 3(3), 98 (2011).

12. B. Togatorop, B.Pharm. Thesis, Department of Pharmaceutical Technology, University of Sumatera Utara, Medan, North Sumatera, Indonesia (2017).

13. Y.S. Tanwar, C.S. Chauhan, A. Sharman, Acta Pharm., 57(2), 151(2007), DOI: 10.2478/v10007007-0012-X.

14. R.C. Rowe, P.J. Sheskey, M.E. Quinn, Handbook of Pharmaceutical Excipients, Pharmaceutical Press and American Pharmacists Association, London, p. 257, 273, 413 (2009).

15. S.V. Kumar, P. Tarun, T.A. Kumar, Indo America Journal of Pharmaceutical Research, 3(5), 3588 (2013), DOI:10.1044/1980-iajpr.00207.

16. V.C. Jhawat, V. Saini, S. Kamboj, N. Maggon, Int. J. Pharm. Sci.,20(1), 47 (2013).

17. G. Haro, S.M. Sinaga, I. Iksen, N. Nerdy, S. Theerachetmongkol, J. App. Pharm. Sci., 7(8), 222 (2017), DOI: $10.7324 / J A P S .2017 .70830$.

18. G. Haro, I. Iksen, R.M. Rumanti, N. Marbun, R.P. Sari, R.P.J. Gultom, Rasayan J. Chem.,11(1), 232 (2018), DOI: 10.7324/RJC.2018.1112011.

19. B. Lakshmi, K.R. Krishna, K.N. Jayaveera, G.V.P. Rao, Rasayan J. Chem.,8(1), 59 (2015)

20. M.V.B. Rao, B.C.K. Reddy, T. Srinivasarao, V. Prasanthi, Rasayan J. Chem.,2(2), 276 (2009).

21. Australian Pesticides and Veterinary Medicines Authority, APVMA Guideline For The Validation of Analytical Method for Active Constituen, Agricultural and Veterinary (2004).

[RJC-2070/2018] 